\title{
ERR A T A
}

Water, Air, and Soil Pollution 5 (1976).

'Sub-Obliterative Effects of Mine-Tailing on Marine Infaunal Benthos', by A. A. Jones and D. V. Ellis, page 307.

The publishers regret that, due to a printing error, four lines intended for the Acknowledgments on the above page were transposed to the opening of the Introduction to

'Groundwater Pollution from a Septic Tile Field', by T. Viraraghavan and R. G. Warnock, page 281.

Also on page 281, the last sentence of the first paragraph should read as follows: Several studies suggest that when $\mathrm{NH}_{3}$ plus nitrate nitrogen is equal to or greater than $0.3 \mathrm{mg} \mathrm{l}^{-1} \mathrm{~N}$ and orthophosphate levels exceed $0.01 \mathrm{mg} \mathrm{l}^{-1} \mathrm{P}$, then a lake is likely to have excessive crops of algae and other aquatic plants. 